\title{
Editorial: South To A New Place
}

In 1971 Albert Murray published South To A Very Old Place. Commissioned by the editor of Harper's magazine, Willie Morris, to write about 'home' in a series of articles, the African American writer produced much more: South To A Very Old Place is memoir, travelogue, social commentary. Orchestrated as a jazz and blues composition, it is a meditation on the American South. Taking his title as our starting point, in this issue of Critical Survey we have gathered contributors who continue the work of critically and creatively mapping the American South, a region that exasperates as it inspires definition(s). Murray's blues forms are open-ended and improvised so the blues metaphor and the jazz form are key in a collection called 'South To A New Place'. It begins to chart connections with 'other' Souths in ways that open up spaces and places from which we might read the South as a site of exchange - the South of Italy in Michael Kreyling's essay; the South as shaped and commodified by the best-selling magazine Southern Living in Amy Elias's essay; and the literary South of Walker Percy and Richard Ford's making in Martyn Bone's essay, for example.

In 'Where is Southern Literature?: The Practice of Place in a Postsouthern Age', Scott Romine wraps his mind around southern literary regionalism from the 1930 s to the present, skilfully analysing the evolution of southern literary scholarship and its fascination with place. Finding that throughout its history the South has been variously defined as a region - geographically, economically, ideologically, culturally, historically and orientationally Romine argues that "all these "Souths" have been subject to or implicated in distinctive forms of representation'. He wonders which criteria will be necessary for 'southern literature' to survive and concludes by speculating on the effect the loss of southern dis- 
tinctiveness will have on the writing of 'southern fiction'. In 'Dismantling the Monolith: Southern Places - Past, Present, and Future', Barbara Ladd tethers the mythic southern balloon back down to earth and has a look around Atlanta and its outlying area, as she speculates about how contemporary scholars might theorise place. Taking her cue from Wendell Berry's incredulity that contemporary scholars of the American South could attempt to 'redefine Southerness without resort to geography', Ladd's wideranging study shows that, although the symbolic landscape of 'the South' continues to shape many of our perceptions, the South is continually undergoing demographic changes. She demonstrates that the South is neither insular nor homogenous, and she argues that while 'the experience of place remains dynamic and vital', it is the theorising of place that is problematic. Sharing a concern with Michael Kowalewski that we 'lack a vocabulary with which to ask engaging philosophical, psychological or aesthetic questions about what it means to dwell in a place, whether actually or imaginatively', Ladd proposes a number of new areas for exploration, some of which other contributors map in detail.

Michael Kreyling goes to Italy in 'Italy and the United States: The Politics and Poetics of "The Southern Problem", to illuminate how both southern regions were 'made' in the 1860s and have been remade since. Via a range of texts and contexts - from early reconciliation romances to the works of Antonio Gramsci, the Southern Agrarians, Norman Douglas and William Faulkner to the rural expeditions of urban intellectuals James Agee and Carlo Levi Kreyling argues that the idea of the 'South' functions similarly in national discourse. He detects a series of 'coincidences' linking Italian and American literature and history, and then demonstrates that the place of the South in both countries shifts from 'historical urgency' to 'cultural politics', and thus from historical to ideological discourse. Anxiety over place - Stephen Flinn Young's idea that we have become 'prisoners of our fascination' with the 'sense' of place - provides the starting point from which Martyn Bone pursues the term 'postsouthern' in a literary context. Engaging with Lewis Simpson and Michael Kreyling's discussions about the term as well as with postmodern geographies, Bone embarks upon an 
innovative examination of both the capitalist production of suburban spaces and the fetishization of place, through Walker Percy's The Moviegoer and that novel's influence on Richard Ford's The Sportswriter. Amy Elias notices the irony that just when southern writers and critics are questioning the notion of a unique southern literature, 'popular culture and the travel industry seem intent upon constructing and marketing southern regional identity'. In 'Postmodern Southern Vacations: Vacation Advertising, Globalization and Southern Regionalism', Elias emphasises how the construction of the American South has become a global issue, and she unpacks the ways in which some advertisements recuperate the Old South's construction of race and others illuminate the New South's anxieties about ethnicity. Her focus on Southern Living, a magazine with a readership of 12 million, reveals a complex fantasy South, which has become a playground for consumers from all over the United States and around the world.

In 'Race and Intimacy: Albert Murray's South To A Very Old Place', Carolyn Jones returns to Murray in order to rethink what it means to dwell in a place, for Murray recognised the hybridity of southern culture long before the concept became trendy in contemporary theoretical circles, and he showed how the South has within its indigenous African American musical forms some of the tools it needs to reconstruct its society. Via Toni Morrison's ideas of 'intimate things in place', Jones argues that in the structure of South To A Very Old Place, Albert Murray illustrates how the blues-inspired jazz form can become a model both to locate the self and to improvise new communities. Through his conversations with white southerners - Robert Penn Warren, C. Vann Woodward, Edwin Yoder, Walker Percy and others - Murray, playing the role of the trickster, tests to see if they will acknowledge the hybridity of southern culture, all the while hoping to spot the 'downhome angle of vision' beneath their cosmopolitan intellectualism and their southern politeness.

Together these essays examine the roles that economic, racial and ideological tensions in the South have played in the formation of 'southern' identity through many different representations of southern places. The contributors recognise how problematic nar- 
ratives of regional consciousness and portraits of southern places continue to be and they challenge southern boundaries and southern regional myths, as they move 'South' towards a 'New Place' in Southern Studies.

SUZANNE W. JONES and SHARON MONTEITH

Guest Editors 